\title{
TAX AVOIDANCE DAN KARAKTERISTIK OPERASIONAL PERUSAHAAN TERHADAP BIAYA HUTANG
}

\author{
Wiwi Idawati' \\ STIE Indonesia Banking School \\ wiwi.idawati@ibs.ac.id \\ Fandi Wisudarwanto ${ }^{2}$ \\ Direktorat Jenderal Pajak \\ fandi.wisudarwanto@gmail.com \\ Diterima 21 Desember 2020 \\ Disetujui 3 Mei 2021
}

\begin{abstract}
The purpose of this research is to obtain empirical evidence of the effect of Tax Avoidance, Institutional Ownership, Operating Cash Flow and Leverage on the Cost of Debt. This study uses a causal-comparative research method with secondary data obtained from the financial statements of property companies. The population in this study were 49 property companies listed on the Indonesia Stock Exchange. The sampling technique was purposive sampling in order to obtain a representative sample of 17 property companies. This study uses multiple regression analysis to test the hypothesis. Based on the research results indicate that Tax Avoidance and Operating Cash Flow do not have a significant effect on the cost of debt and collectively tax avoidance, institutional ownership, operating cash flow, leverage simultaneously affect the cost of debt.
\end{abstract}

Keywords: Tax Avoidance; Institutional Ownership; Operating Cash Flow; Leverage; Cost of Debt

\section{PENDAHULUAN}

\subsection{Latar Belakang}

Sumber APBN Negara berasal dari Tax oleh karena itu pajak punya peran penting untuk memenuhi kebutuhan belanja negara dan juga pembangunan infrastruktur negara (Iqbal, 2015). Salah satu indikator yang dapat meningkatkan pendapatan negara adalah berasal dari pajak oleh karena itu letak strategis suatu negara akan mempengaruhi tingkat pendapatan negara dari sektor pajak (Endriati, et al 2013) .

Berdasarkan data Dashboard Penerimaan DJP, yang mencakup seluruh pendapatan pajak baik penerimaan Pajak Non Migas maupun Pajak Migas, diperoleh capaian persentase realisasi penerimaan pajak selama tiga tahun terakhir adalah sebagai berikut:

Tabel 1. Realisasi Penerimaan Pajak Tahun 2015-2019

\begin{tabular}{|c|r|r|c|}
\hline \multirow{2}{*}{ Tahun } & \multicolumn{2}{|c|}{ Penerimaan Pajak } & Realisasi Terhadap Target \\
\cline { 2 - 3 } & Target & \multicolumn{1}{c|}{ Realisasi } & $(\%)$ \\
\hline 2015 & $1.294,2$ Triliun & 1.060 Triliun & $82,0 \%$ \\
\hline 2016 & $1.355,2$ Triliun & $1.105,81$ Triliun & $81,6 \%$ \\
\hline
\end{tabular}




\begin{tabular}{|l|r|r|l|}
\hline 2017 & $1.283,6$ Triliun & $1.151,1$ Triliun & $89,7 \%$ \\
\hline 2018 & 1.424 Triliun & $1.315,9$ Triliun & $92,4 \%$ \\
\hline 2019 & $1.577,56$ Triliun & $1.332,1$ Triliun & $84,4 \%$ \\
\hline
\end{tabular}

Sumber : DJP (2019)

Mengacu pada Tabel 1 di atas dapat dijelaskan bahwa realiasi pajak belum sesuai dengan target yang ditetapkan. Mengacu pada Tabel 1.1 di atas dapat dijelaskan bahwa realiasi pajak belum sesuai dengan target yang ditetapkan. Salah satu faktor belum tercapainya target penerimaan pajak adalah karena ada nya usaha dari perusahaan untuk meminimalkan biaya pajak melalui penghindaran pajak. Menurut Lim (2011) tax planning yang dilakukan untuk menurunkan biaya pajak merupakan salah satu bentuk penghindaran pajak.

Sesuai tujuan mengoptimalkan laba, perusahaan baik domestik maupun multinasional berusaha meminimalkan beban pajak dengan memanfaatkan ketentuan pajak yang ada (Soemitro \& Dewi 2010). Penghindaran pajak merupakan perlawanan aktif yang berasal dari wajib pajak menyebabkan banyak wajib pajak yang tidak patuh pada aturan perpajakan dengan cara mengurangi pajaknya (Kholbadalov, 2012).

Penelitian ini dilakukan pada sektor properti, hal ini karena adanya fenomena bahwa sektor properti sangat intensif dalam melakukan manajemen pajak. Hal ini didukung suatu pengamatan oleh Direktorat Jenderal Pajak dimana menyebutkan banyak pengembang sektor properi dalam membuat SPT dengan sengaja melakukan kesalahan.

Berdasarkan pendapat EG sebagai ketua Apersi mengatakan bahwa ada pengembang industri properti yang tidk memiliki integritas dalam mengembangkan bisnisnya dimana pajak yang dibayarkan dari NJOP padahal seharusnya dari harga yang lebih tinggi karena harga jual properti cenderung naik, hal ini yang menyebabkan kebocoran pendapatan negara sebesar Rp. 30 - 40 triliyun (Kontan.co.id, 25 Juni 2013).

Disamping itu, Pelonggaran aturan KPR dinilai akan membantu perusahaan properti terutama di sisi arus kas. Seperti diketahui, bersamaan dengan pemangkasan BI rate, Bank Indonesia juga melonggarkan aturan KPR. Saat ini, KPR rumah kedua dapat digunakan untuk membeli rumah yang masih dalam proses konstruksi. Secara garis besar, uang muka (down payment) yang harus disetor oleh nasabah turun menjadi rata-rata $15 \%$ dari semula $20 \%$ sesuai dengan tipe dan jenis rumah yang diambil. Selain itu, lanjutnya, BI juga memperlonggar kredit atau pembiayaan melalui mekanisme indent dengan pengaturan pencairan kredit atau pembiayaan bertahap sesuai progress pembangunan untuk rumah tapak, rumah susun, dan ruko atau rukan sampai dengan fasilitas kredit maupun pembiayaan kedua. Insentif tersebut juga berlaku bagi nasabah yang mengambil fasilitas pembiayaan dengan prinsip syariah (http://infobanknews.com).

Masri dan martani (2012) melakukan penelitian tentang pengaruh tax avoidance terhadap cost of debt, hasil penelitiannya menyimpulkan penghindaran pajak berpengaruh 
positif terhadap cost of debt. Sedangkan bertentangan dengan hasil penelitian dari Lim (2011) yang menyatakan bahwa tax avoidance berpengaruh negatif terhadap cost of debt.

Adanya keterbatasan hasil penelitian terdahulu merupakan apresiasi untuk mengembangkan penelitian lebih lanjut terkait dengan cost of debt dari penelitian Septian (2017) terkait dengan beban hutang yang dipengaruhi oleh Tata Kelola Perusahaan yang terdiri dari kepemilikan manajerial, dewan komisaris independen, kualitas audit dan kepemilikan keluarga serta kepemilikan institusional dengan unit analisis pada perusahaan yang terdaftar di Kompas 100 untuk tahun 2013 sd 2014 dengan regresi linear berganda menggunakan aplikasi SPSS sehingga penelitian ini berbeda dengan hasil penelitian terdahulu dimana cost of debt dipengaruhi oleh beberapa faktor diantaranya Tax avoidance, institutional ownership, operating cash flow, leverage, Debt costs dengan unit analsisisnya adalah perusahaan Properti untuk laporan keuangan tahun $2016 \mathrm{sd}$ 2019 dengan program aplikasi statistik komputer Eviews 9.0 dan data yang digunakan adalah panel data.

\subsection{Rumusan Masalah}

Berdasarkan latar belakang penelitian, maka rumusan masalah penelitian ini adalah sebagai berikut

1. Apakah Tax Avoidance berpengaruh terhadap biaya hutang ?

2. Apakah Instituisional manajerial berpengaruh terhadap biaya hutang ?

3. Apakah Cash Flow Operation berpengaruh terhadap biaya hutang ?

4. Apakah Leverege berpengaruh terhadap biaya hutang ?

5. Apakah penghindaran pajak, kepemilikan institusional, arus kas operasi, leverage, secara bersama-sama terhadap biaya hutang ?

\subsection{Tinjauan Literatur dan Hipotesis \\ 1.2.1 Teori Keagenan}

Agency Theory dapat diartikan sebagai konflik kepentingan antara manajemen dan pemilik perusahaan. Manajemen menganggap bahwa perusahaan yang dikelola merupakan bagian dari keberhasilan mereka melaksanakan tugas dan tanggung jawabnya sehingga menjadi perusahaan yang berkembang dan berkelanjutan (Jensen, \& W. Meckling 1976.).

Manajemen terkadang mengambil suatu keputusan yang tidak sesuai dengan yang diharapkan oleh investor sehingga konflik keagenan yang adanya pemisahan peran atau perbedaan kepentingan antara principal dengan agen akan menimbulkan konflik keagenan (Graham \& Tucker, 2006). Kualitas informasi yang dihasilkan oleh manajamen merupakan hal yang tidak bisa dihindari agar dapat mengurangi asimetris informasi.

\subsubsection{Tax Avoidance}

Penghindaran pajak saat ini disoroti dengan memanfaatkan celah- celah hukum perpajakan yang dari aspek moralitas dan sifat keagresifannya (Dyreng, et al, 2008). Penghindaran pajak didalam penerapannya perusahaan menggunakan penerapan mengurangi pajak yang bersifat legal. Selama ini penghindaran pajak merupakan suatu langkah untuk meringankan beban pajak suatu perusahaan dengan tidak melanggar undang - undang yang ada sehingga dengan menerapkan tax avoidance dapat memberikan keuntungan bagi perusahaan karena perusahaan tidak membayarkan penuh beban pajaknnya sehingga laba yang dihasilkan akan meningkat ( Ferdiawan \& Firmansyah, 2017). Sebagai istilah alternatif dari 'tax sheltering' dan 'tax planning'. Dapat mengurangi jumlah pajak tanpa mengubah substansi ekonomi dan 'tidak melanggar ketentuan hukum pajak (Graham \& Tucker, 2006). 


\subsubsection{Kepemilikan Institusional}

Kepemilikan institusional adalah persentase saham perusahaan yang dimiliki oleh institusi atau lembaga (perusahaan asuransi, dana pensiun, atau perusahaan lain).Institusional Ownership merupakan presentase saham yang dimiliki oleh institusi atau lembaga yang sangat bergantung pada besarnya investasi dan dapat meminimalkan konflik keagenan manager dengan para pemegang saham (Fitriyah \& Hidayat,2011). Para agent yang memiliki tingkat profesional yang tinggi dan melaksanakan tugas untuk mengelola suatu bisnis untuk dapat meningkatkan nilai perusahaan.

\subsubsection{Cash Flow from Operating}

Arus kas operasi dapat diartikan sebagai aliran kas masuk sebanyak uang tunai yang dihasilkan oleh bisnis dari kegiatan operasinya. Pengguna laporan keuangan sangat membutuhkan informasi dari aliran kas untuk mereka memahami serta menilai entitas dalam mencapai tujuannya (Herlambang, 2017). Kemampuan entitas untuk memperoleh kas dan setara kas untuk mengetahui kas dan setara kas apa saja yang akan digunakan dengan kas dan setara kas dengan tidak memperhitungkan investasi modal apa pun yang diperlukan (Warsidi, et al 2009).

\subsubsection{Leverage}

Rasio keuangan yang dapat mengukur pencapaian perusahan dalam menggunakan hutang sehingga pembiayaan membutuhkan aktiva berupa fixed cost yaitu liabilitas dan saham preferen (Kurniasih, et al 2013). Analisis leverage menunjukan kemampuan perusahaan memenuhi kewajibannya dalam jangka panjang (Subramanyam, 2014). Leverage menunjukkan rasio tingkat aset yang dibiayai oleh hutang. Semakin tinggi nilai Leverage maka semakin tinggi pula resiko yang akan dihadapi oleh investor. Perusahaan yang memiliki Leverage yang tinggi akan memiliki kewajiban yang tinggi untuk untuk memenuhi kebutuhan informasi kreditur. Sehingga semakin tinggi hutang perusahaan, maka leverage dan risiko yang dihadapi perusahaan akan semakin besar.

\subsection{6 .Beban Hutang (Cost of Debt)}

Menurut Sugiono (2018) Beban hutang adalah biaya hutang yang berasal dari pinjaman adalah merupakan bunga yang harus dibayar perusahaan. Selanjutnya Warsono (2017) Beban hutang merupakan before-tax cost of debt dan after-tax cost of debt

Mengukur cost of debt dalam periode satu tahun dibagi dengan jumlah rata-rata pinjaman jangka panjang dan jangka pendek yang berbunga selama tahun tersebut (Lim, 2011). Bagi perusahaan biaya utang yang diberikan oleh kreditur atas suatu pendanaan merupakan hal yang sangat penting, misalkan anda mengajukan sebuah hutang ke bank, maka kreditur maka beban yang akan ditanggung perusahaan juga akan semakin kecil sehingga akan berdampak positif bagi laba yang dihasilkan (Fabozzi, 2007).

\subsection{Pengembangan Hipotesis.}

Berikut pengembangan hipotesis penelitian ini berdasarkan hasil penelitian terdahulu tersebut yang dilihat dari faktor akuntansi yaitu: penghindaran pajak, kepemilikan institusional, arus kas operasi, leverage dan biaya hutang.'

\subsubsection{Tax Avoidance terhadap Cost of Debt.}

Menurut Masri \& martani (2012) melakukan penelitian tentang pengaruh tax avoidance terhadap cost of debt, yang mana tujuan dari penelitian tersebut adalah untuk menganalisis 
perilaku penghindaran pajak terhadap biaya hutang yang dimoderatori oleh perubahan tarif pajak dan struktur kepemilikan keluarga. Studi ini menemukan bahwa penghindaran pajak berpengaruh positif terhadap cost of debt. Sedangkan Marcelliana dan Purwaningsih (2013) melakukan penelitian dengan judul The relationship of corporate tax avoidance, cost of debt and institutional ownership: evidence from Malaysia. Hasil penelitian menunjukkan bahwa penghindaran pajak berhubungan negatif dengan biaya hutang dan hubungan antara penghindaran pajak perusahaan dan biaya utang dimoderatori oleh tingkat kepemilikan institusional

\section{H1 : Terdapat Pengaruh Tax Avoidance terhadap Cos of Debt.}

\subsubsection{Pengaruh Kepemilikan Institusional terhadap.}

Christopher et.al (2012) penelitian tentang governance, incentives, and tax avoidance membahas hubungan antara tata kelola perusahaan, insentif manajer, dan penghindaran pajak. Penelitian ini memiliki perspektif bahwa penghindaran pajak hanyalah salah satu dari banyak proyek-proyek investasi yang dihadapi oleh masalah perusahaan dan badan dapat menyebabkan manajer untuk over-investasi atau di bawah-berinvestasi di penghindaran pajak relatif terhadap keinginan pemegang saham. Menggunakan regresi ditemukan bahwa tata kelola perusahaan, insentif bagi manajer berpengaruh signifikan terhadap penghindaran pajak perusahaan. Selajutnya menurut (Ngadiman \& Puspitasari,2014) hasil penelitiannya menunjukan memiliki perspektif bahwa penghindaran pajak hanyalah salah satu dari banyak proyek-proyek investasi yang dihadapi oleh masalah perusahaan dan badan dapat menyebabkan manajer untuk over-investasi atau di bawahberinvestasi di penghindaran pajak relatif terhadap keinginan pemegang saham.

\section{H2 : Terdapat Pengaruh Kepemilikan Institusional terhadap Cos of Debt}

\subsubsection{Pengaruh Arus Kas Operasi terhadap Biaya Hutang.}

Chandra (2017). Hasil peneletian menunjukkan variabel arus kas bebas dan profitabilitas memiliki pengaruh yang signifikan dan memiliki hubungan yang kuat dengan arah positif terhadap kebijakan utang. Fitriyah dan Dina (2011) melakukan penelitian untuk mengetahui pengaruh arus kas bebas dan profitabilitas pada kebijakan utang perusahaan real estate di Bursa Efek Indonesia. Berdasarkan hasil analisis regresi linier didapatkan bahwa arus kas bebas tidak berpengaruh signifikan terhadap kebijakan utang perusahaan.

\section{H3: Terdapat Pengaruh Arus Kas Operasi terhadap Cos of Debt}

1.3.4 Pengaruh Leverage terhadap Biaya Hutang. Hasil penelitian sebelumnya, Swingly dan Sukartha (2015) menyatakan bahwa leverage berpengaruh negatif secara signifikan terhadap tax avoidance yang artinya semakin tinggi rasio leverage, maka semakin rendah kemungkinan perusahaan melakukan tax avoidance. Hal ini disebabkan biaya bunga yang harus dibayarkan perusahaan telah mengurangi laba sebelum pajak. Berbeda dengan Saputra et al (2017), yang menyatakan bahwa leverage berpengaruh positif secara signifikan terhadap pemghindaran pajak.

\section{H4 : Terdapat Pengaruh Leverage terhadap Cos of Debt.}

\subsection{Model Penelitian}




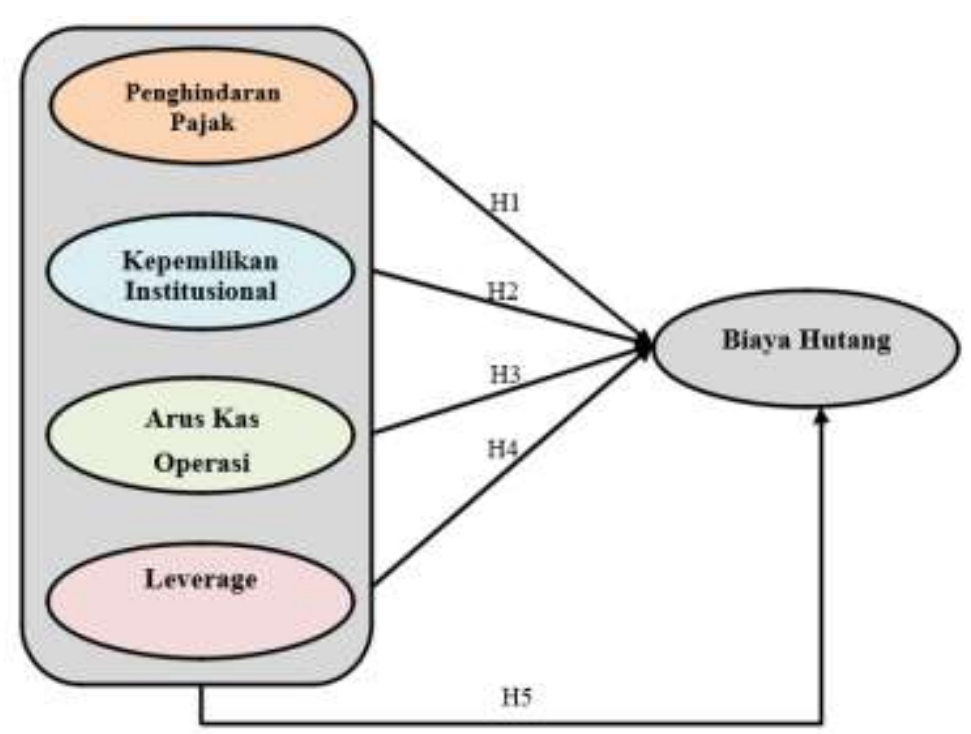

Gambar 1. Model Penelitian

\section{METODOLOGI PENELITIAN}

\subsection{Gambaran Umum Objek Penelitian}

Objek penelitian adalah laporan keuangan perusahaan properti untuk memenuhi varibel penghindaran pajak, kepemilikan institusional, arus kas operasi, leverage dan biaya hutang. Populasi dalam penelitian ini adalah seluruh perusahaan properti yang terdaftar di BEI periode 2015 - 2019.Terdapat 49 perusahaan yang terdaftar di BEI. Penelitian ini menggunakan metode non probability sampling yaitu metode pengambilan sampel yang tidak memberikan peluang/kesempatan yang sama bagi setiap unsur atau anggota populasi untuk dipilih menjadi sampel.Teknik pengambilan sampel dilakukan seara purposive sampling dengan tujuan untuk mendapatkan sampel yang representatif sesuai dengan kriteria yang ditentukan. Adapun beberapa kriteria yang ditetapkan sebagai dasar pemilihan sampel adalah Perusahaan properti yang memiliki dan menyampaikan laporan keuangan secara lengkap tahun 2015-2019, Perusahaan properti yang memiliki hutang selama tahun 2015-2019 Perusahaaan properti yang menyampaikan laporan keuangan dalam mata uang Rupiah tahun 2015-2019, kriteria ini diperlukan agar pengukuran nilai mata uangnya sama dan perusahaan tidak mengalami delisting selama tahun pengamatan.

\subsection{Metode Penelitian}

Penelitian ini menggunakan metode penelitian kuantitatif korelasional merupakan penelitian yang bertujuan menjelaskan hubungan korelasional antara satu variabel yang mempengaruhi variabel lainnya ( Sanusi, 2011) melalui pengujian hipotesa, yang mana dalam penelitian ini bertujuan untuk mengetahui pengaruh variabel bebas (tax avoidance, kepemilikan institusional, arus kas operasi dan leverage) terhadap variabel terikat (biaya hutang). Jenis data yang digunakan dalam penelitian ini adalah data sekunder, berupa data laporan keuangan. Data sekunder dalam penelitian ini bersumber dari Indonesian Capital Market Directory (ICMD) dan Bursa Efek Indonesia. Teknik pengumpulan data dilakukan dengan cara melakukan pengamatan dan pencatatan atas setiap item yang diperlukan dalam laporan keuangan perusahaan properti selama tahun 2015-2019.

\subsection{Penelitian}

\subsubsection{Variabel Dependen}


Variabel dependen pada penelitian ini adalah biaya utang merupakan tingkat yang harus diterima dari investasi untuk mencapai tingkat pengembalian (yield rate) yang dibutuhkan oleh kreditur atau dengan kata lain adalah tingkat pengembalian yang dibutuhkan oleh kreditur saat melakukan pendanaan dalam suatu perusahaan (Fabozzi, 2007).

\title{
2.3.2. Variabel Independen
}

\section{Tax Avoidance}

Dalam konteks perusahaan, tax avoidance sengaja dilakukan oleh perusahaandalam rangka memperkecil tingkat pembayaran pajak yang harus dilakukan dan sekalian meningkatkan cash flow perusahaan. Dalam konteks pendapatan negara, tax avoidance telah membuat negara kehilangan potensi pendapatan pajak yang seharusnya dapat digunakan untuk mengurangi beban defisit atas anggaran negara (Budiman dan Setiyono, 2012). Indikator dalam penelitian ini adalah

$$
\text { ETR }=\frac{\text { Beban Pajak }}{\text { EBIT }}
$$

\section{Kepemilikan Institusional (Institutional Ownership)}

Institusional Ownership merupakan struktur kepemilikan yang terdiri dari institusi asing, pemerintah, institusi domestik, institusi asing, pemerintah, individual individual domestic dan karyawan (Juniarti dan Santoso, 2009). Para manager akan meningkatkan pengendalian internal agar jumlah presentase kepemilikan saham yang dimiliki oleh pihak institusi dapat dipertanggung jawabkan. Dalam penelitian ini untuk menghitung kepemiikan institusional sebagai berikut:

$$
\text { KEPINS }=\frac{\text { Jumlah kepemilikan saham oleh institusi }}{\text { Total jumlah lembar saham beredar }}
$$

\section{Cash Flow from Operating}

Arus kas operasi diawali dari laba bersih termasuk biaya yang belum dibayarkan menggunakan akuntansi berbasis akrual. cash flow statement merupakan laporan keuangan yang memberikan informasi terkait aktivitas operasi, pendanaan, dan investasi perusahaan. Dalam penelitian ini untuk menghitung arus kas operasi adalah

$$
\mathrm{CF}=\frac{\text { Arus kas operasi }}{\text { Total Aset }}
$$

\section{Leverage}

Definisi leverage menurut Sugiono (2018) adalah penggunaan hutang untuk membiayai investasi. Leverage merupakan rasio yang mengukur seberapa jauh perusahaan menggunakan hutang dalam pembiayaan.

\author{
DER $=\underline{\text { Total Hutang }}$ \\ Total Ekuitas
}

\subsection{Teknik Pengumpulan Data}


Metode ini dilakukan dengan cara mengumpulkan seluruh informsi dan data sekunder yang dibutuhkan oleh peneliti. Data tersebut didapatkan dari laporan keuangan perusahaan manufakt yang terdaftar di Bursa Efek Indonesia selama periode tahun 20152019 yang laporan keuangan perusahaan didapatkan dari Website resmi masing - masing perusahaan.

\subsection{Teknik Pengambilan Sampel}

Teknik pengambilan sampel dilakukan seara purposive sampling dengan tujuan untuk mendapatkan sampel yang representatif sesuai dengan kriteria yang ditentukan. Adapun beberapa kriteria yang ditetapkan sebagai dasar pemilihan sampel adalah Corporation properti menujukankan data yang lengkap dalam laporan keuangan secara lengkap tahun 20152019.Perusahaan properti yang memiliki hutang selama tahun 2015-2019.Perusahaaan properti yang menyampaikan laporan keuangan dalam mata uang Rupiah tahun 2015-2019. Kriteria ini diperlukan agar pengukuran nilai mata uangnya sama.Perusahaan tidak mengalami delisting selama tahun pengamatan.

\subsection{Teknik Analisis Data}

Dalam penelitian ini metode analisis data yang digunakan yaitu analisis regresi berganda, yang bertujuan menguji pengaruh variabel biaya hutang, kepemilikan institusional, arus kas operasi, dan leverage terhadap penghindaran pajak. Adapun model dapat di rumuskan sebagai berikut :

\section{CDEB i,t $=\beta_{0}+\beta_{1}$ ETRi,t $+\beta_{2}$ KEPINS,t $+\beta_{3} C F i, t+\beta_{4} D E R i, t+\varepsilon i, t$}

Keterangan :

$\begin{array}{ll}\text { CDEB } \beta_{0} & : \text { Biaya Hutang } \\ & : \text { Konstanta } \\ \beta_{1}-\beta_{5} & : \text { Koefisien Regresi } \\ \mathrm{i}, \mathrm{t} & : \text { Perusahaan, Periode Laporan Tahunan } \\ \text { ETR } & : \text { Tax Avoidance } \\ \text { KEPIN } & : \text { Kepemilikan Institusional } \\ \mathrm{S} & : \text { Cash Flow Operating } \\ \mathrm{CF} & : \text { Leverage } \\ \mathrm{DER} & : \text { Nilai Residual } \\ \varepsilon & : \text { Error }\end{array}$

\section{HASIL PENELITIAN DAN DISKUSI} 3.1 Statistik Deskriptif

\begin{tabular}{lccccc}
\multicolumn{7}{c}{ Tabel 1. Analisis Deskriptif Data } \\
& HUTANG & ETR & KEPINS & CF & DER \\
\hline Mean & 0.034910 & 0.187126 & 0.545162 & 0.043769 & 1.29410 \\
Median & 0.029574 & 0.139008 & 0.579668 & 0.030713 & 0.97205 \\
Maximum & 0.169749 & 3.074009 & 0.888829 & 0.288459 & 11.1656 \\
Minimum & $5.51 E-05$ & 0.000165 & 0.001296 & -0.192475 & 0.07376 \\
Std. Dev. & 0.030987 & 0.344805 & 0.247740 & 0.084320 & 1.41909 \\
Observations & 85 & 85 & 85 & 85 & 85 \\
\hline
\end{tabular}


Berdasarkan hasil Uji statistik deskriptif pada table 1 dapat dijelaskan variabel biaya hutang (HUTANG) memiliki nilai terkecil (minimum) sebesar 5,51E-05 dan terbesar (maximum) adalah 0,169749 dengan rata-rata (mean) sebesar 0,034910. Variabel penghindaran pajak (ETR) nilai minimun sebesar 0.000165 dan maximum adalah 3,074009 dengan rata-rata (mean) sebesar 0,187126. Data variabel kepemilikan institusional (KEPINS) minimum adalah 0,001296 dan nilai tertinggi adalah 0,888829. Disamping itu nilai kepemilikan institusional (KEPINS) dengan nilai rata-rata sebesar 0,545162. Variabel arus kas operasi (CF) memiliki nilai terendah sebesar -0,192475 dan tertingi adalah 0,288459 dengan rata-rata (mean) sebesar 0,043769. Variabel leverage (DER) dengan nilai terendah 0,073786 dan nilai tertinggi 11,16586 dengan mean 1,294170.

\subsection{Pemilihan Metode Regresi Data Panel. Uji Fixed Effect (Uji Chow)}

Tabel 2. Hasil Uji Chow
Redundant Fixed Effects Tests
Pool: PANEL
Test cross-section fixed effects

Pada Tabel 2 dapat dilihat bahwa nilai probabilitas uji $\mathrm{F}$ maupun chi-square lebih besar dari 0,05. Dengan demikian, Ho diterima dan H1 ditolak. Artinya, pendekatan estimasi model mengikuti common effect model. Dengan kata lain, common effect model lebih baik dari pada fixed effect model.

\subsection{Uji Random Effect (Uji Hausman)}

Tabel 3.Hasil Uji Hausman

\begin{tabular}{lrrrr} 
Test cross-section random effects & & & \\
\hline Test Summary & $\begin{array}{c}\text { Chi-Sq. } \\
\text { Statistic }\end{array}$ & Chi-Sq. d.f. & Prob. \\
\hline Cross-section random & 4.301812 & 4 & 0.3667 \\
\hline Sumber: Data sekunder yang diolah & & &
\end{tabular}

Pada Tabel 3 dapat dilihat bahwa nilai probability pada test cross section random memperlihatkan angka bernilai 0,3667 lebih besar dari alpha (0,05). Sehingga keputusan yang diambil pada pengujian Hausman test ini yaitu Ho diterima dan model mengikuti metode random effect model. Atau dapat disimpulkan bahwa metode random effect model lebih baik daripada metode fixed effect model.

\subsection{Koefisien Determinasi $\left(\mathbf{R}^{2}\right)$}

Koefisien determinasi $\left(\mathrm{R}^{2}\right)$ pada intinya mengukur seberapa jauh kemampuan model dalam menerangkan variasi variabel dependennya. Nilai $R^{2}$ yang mendekati satu berarti variabelvariabel independennya memberikan hampir semua informasi yang dibutuhkan untuk memprediksi variasi variabel dependen (Ghozali, 2006). Hasil perhitungan koefisien determinasi tersebut dapat terlihat pada Tabel 4.9 sebelumnya.

\section{R-squared sebesar $\mathbf{0 , 1 1 7 5 2 2}$}


Berdasarkan hasil pengolahan data, nilai $\mathrm{R}^{2}$ adalah sebesar 0,117522. (11,75\%). Hal ini menunjukkan bahwa besar pengaruh variabel earning tax rate (ETR), kepemilikan institusional (KEPINS), cash flow from operation (CFO) dan debt to equity ratio (DER) terhadap biaya hutang yang dapat diterangkan oleh model persamaan ini adalah sebesar $11,75 \%$ dan sisanya sebesar $88,25 \%$ dipengaruhi oleh faktor-faktor lain yang tidak dimasukkan dalam model regresi.

\subsection{Uji F}

Uji $\mathrm{F}$ digunakan untuk menguji pengaruh semua variabel independen atau variabel bebas secara bersama-sama terhadap variabel dependen atau variabel terikat (Priyatno, 2011:258). Hasil perhitungan Uji F pada penelitian ini dapat dilihat pada Tabel 4.9 sebelumnya:

\section{F-statistic \\ Prob(F-statistic)}

\section{2,663451}

$\mathbf{0 , 0 3 8 2 8 0}$

\subsection{Uji Parsial (Uji T)}

Hasil perhitungan analisis regresi guna menguji hipotesis-hipotesis yang diajukan dapat dilihat pada Tabel 4 berikut:

\section{Tabel 4.Hasil Uji t}

\begin{tabular}{crrl}
\hline Variable & Coefficient & t-Statistic & Prob. \\
\hline \hline C & 0.064690 & 8.080657 & 0.0000 \\
ETR & -0.002844 & -0.404801 & 0.6867 \\
KEPINS & -0.037209 & -4.867258 & 0.0000 \\
CF & -0.064335 & -1.897294 & 0.0614 \\
DER? & -0.004750 & -2.069472 & 0.0417 \\
\hline \hline
\end{tabular}

Sumber: Data sekunder yang diolah

Dari hasil analisis regresi di atas, dapat dilihat bahwa variabel earning tax rate (ETR), cash flow from operation (CFO) dan debt to equity ratio (DER) tidak memiliki pengaruh signifikan terhadap variabel dependen yaitu biaya hutang. Hal ini ditunjukkan dari nilai Prob. dari masing-masing variabel yang lebih besar dari tingkat signifikasi 0,05. Sedangkan variabel kepemilikan institusional (KEPINS) memiliki nilai signifikansi lebih kecil dari alpha 0,05 yang artinya memiliki pengaruh signifikan.

\subsection{Pembahasan}

\subsubsection{Pengaruh Penghindaran Pajak terhadap Biaya Hutang}

Hasil penelitian ini menjelaskan bahwa manajemen perusahaan properti tidak melakukan kebijakan pajak agresif, hal ini terkait dengan karakteristik jenis pajak perusahaan properti, dimana sebagian besar pajak penghasilan perusahaan properti dikenakan pajak final, hal ini membuat manajemen perusahaan tidak banyak melakukan upaya penghindaran pajak. Kondisi ini tercermin dari nilai rata-rata tax avoidance perusahaan properti yang hanya sebesar $18,7 \%$, artinya tingkat beban pajak yang ditanggung perusahaan masih relatif rendah dibandingkan dengan tingkat pajak penghasilannya.

Hasil penelitian ini sejalan dengan dengan Purwanti (2014) yang menemukan bahwa penghindaran pajak tidak memiliki pengaruh signifikan terhadap biaya hutang. Kondisi ini 
mengindikasikan bahwa ada atau tidaknya kegiatan penghindaran pajak yang dilakukan oleh manajemen tidak dapat dijadikan sebagai acuan dalam melakukan penambahan atau pengurangan hutang perusahaan. Namun demikian, hasil penelitian ini berlawanan dengan temuan Desai dan Dharmapala (2014) yang menemukan adanya pengaruh signifikan dengan arah hubungan negatif antara penghindaran pajak dengan biaya hutang.

\subsubsection{Pengaruh Kepemilikan Institusional terhadap Biaya Hutang}

Hasil penelitian ini menjelaskan bahwa kepemilikan saham institusional pada perusahaan properti terbukti efektif dalam mengurangi biaya hutang perusahaan, hal ini ditunjukkan oleh nilai rata-rata kepemilikan institusional perusahaan properti yang mencapai 54,5\%atau saham properti secara dominan dikuasai oleh pihak institusi. Hasil ini sejalan dengan pernyataan Ayu dan Putri (2017) bahwa kehadiran kepemilikan institusional dapat mengurangi hutang perusahaan dalam rangka meminimalkan total biaya keagenan hutang (agency cost of debt). Maharani (2019) menerangkan dengan adanya pemegang saham besar seperti kepemilikan institusional memiliki arti penting dalam memonitor manajemen dengan pengawasan yang lebih optimal.

\subsubsection{Pengaruh Arus Kas Operasi terhadap Biaya Hutang}

Hasil penelitian ini menunjukkan bahwa arus kas operasi tidak berpengaruh signifikan terhadap biaya hutang,.Hal ini dikarenakan perusahaan dengan arus kas yang tinggi artinya memiliki dana internal yang besar yang dapat digunakan untuk membiayai pertumbuhan perusahaan tanpa harus melakukan pinjaman dari pihak eksternal. Sehingga manajemen tidak perlu mempertimbangkan perlunya pendanaan tambahan dari pihak lain yang berupa utang. Hasil penelitian ini sejalan dengan penelitian Chandra (2017) hubungan yang tidak signifikan antara free cash flow disebabkan karena perusahaan akan mengutamakan penggunaan dana internal untuk kebutuhan investasi dan kegiatan operasionalnya, sehingga jika perusahaan mempunyai dana internal yang cukup maka perusahaan tidak akan menggunakan dana eksternal untuk mencukupi kebutuhan pendanaannya.

\subsubsection{Pengaruh Leverage terhadap Biaya Hutang}

Hasil penelitian ini menunjukkan bahwa leverage berpengaruh signifikan terhadap biaya hutang. Kondisi ini mengindikasikan bahwa leverage yang ada pada perusahaan dapat menentukan tingkat biaya hutang yang akan diambil oleh suatu perusahaan. Leverage sebagai ukuran dari modal pinjaman atau utang yang digunakan untuk membiayai aktiva perusahaan memiliki pengaruh terhadap biaya hutang perusahaan. Dalam kondisi rasio hutang yang cukup tinggi, maka manajemen perusahaan property sebaiknya mengontrol penggunaan hutang karena jika tidak dikelola secara baik maka hutang dapat membawa risiko kebangkrutan sebagai akibat dari membengkaknya biaya bunga (Wahyuni dan Atmaja.2019)

Menurut Darmawan (2014) rasio leverage merupakan alat untuk mengukur kemampuan perusahaan dalam memenuhi kewajiban yang besifat tetap. Selanjutnya (Kurniasih, et al 2013).menyatakan rasio hutang yang cukup tinggi, maka manajemen perusahaan properti sebaiknya mengontrol penggunaan hutang karena jika tidak dikelola secara baik maka hutang dapat membawa risiko kebangkrutan sebagai akibat dari membengkaknya biaya bunga. 


\section{KESIMPULAN DAN SARAN}

\subsection{Kesimpulan}

Simpulan yang diperoleh dari penelitian ini adalah:

1. Penghindaran pajak terbukti tidak memiliki pengaruh terhadap biaya hutang pada perusahaan propert Hasil ini menunjukkan bahwa perusahaan properti tidak terlalu agresif dalam melakukan penghindaran pajak.

2. Kepemilikan institusional terbukti memiliki pengaruh terhadap biaya hutang pada perusahaan property. Hasil ini menunjukkan bahwa efektif bagi perusahaan properti untuk meningkatkan jumlah kepemilikan saham untuk investor institusional karena dapat mengontrol perilaku oportunistik dari manajemen dalam melakukan kebijakan hutang.

3. Arus kas operasi terbukti tidak memiliki pengaruh terhadap biaya hutang pada perusahaan property. Hasil ini menunjukkan bahwa arus kas operasi lebih cenderung diperuntukkan untuk pelaksanaan operasional perusahaan bukan dalam upaya perusahaan untuk mengurangi biaya hutang.

4. Leverage terbukti memiliki pengaruh terhadap biaya hutang pada perusahaan property.Hasil ini menunjukkan bahwa penggunaan hutang yang dilakukan oleh perusahaan properti akan berdampak terhadap peningkatan biaya hutang melalui kenaikan beban pokok dan biaya bunga.

\subsection{Keterbatasan}

Terdapat beberapa hal yang merupakan keterbatasan dalam penelitian ini yaitu:

1. Pengukuran Tax Aviodance tidak melalui tahapaan Perencanaan pajak yang dilakukan manajemen dan juga tidak melibatkan pengukuran pengendalian internal yang ada sehingga akan menyebabkan lemahmya pengawasan,sehingga kontrol atas pengendalian hutang atau aset sangat lemah bagi perusahaan

2. Berdasarkan Dengan demikian perlu adanya perluasan variabel penelitian sehingga dapat memberikan implikasi managerial yang lebih luas dan menyeluruh.

\subsection{Saran}

Saran yang diajukan dalam penelitian ini adalah

1. Perusahaan disarankan melakukan kebijakan perencanaan pajak yang profesional, atau tidak melakukan upaya penghindaran pajak secara agresif, karena hal ini akan berdampak terhadap kinerja perusahaan dan biaya hutang.

2. Bagi penelitian selanjutnya disarankan menambahkan rasio keuangan lainnya sebagai variabel independen, karena sangat dimungkinkan rasio keuangan lain yang tidak dimasukkan dalam penelitian ini berpengaruh kuat terhadap biaya hutang seperti mekanisme GCG dan nilai perusahaan. Selain itu menambahkan periode pengamatan sehingga nantinya diharapkan hasil yang diperoleh akan lebih dapat digeneralisasikan dan untuk memperluas penelitian serta menghasilkan analisis yang lebih baik.

\subsection{Implikasi Penelitian}

Berdasarkan hasil penelitian ini diharapkan manajemen perusahaan dapat mengelola arus kas operasi secara efisien dan efektif karena arus kas yang lancar akan membuat 
fundamental keuangan perusahaan menjadi lebih baik sehingga perusahaan tidak melakukan penghindaran pajak secara agresif dengan demikian perusahaan harus menaati Peraturan Menteri Keuangan No. 169/PMK.010/2015 tentang Penentuan Besarnya Perbandingan antara Utang dan Modal Perusahaan untuk Keperluan Penghitungan Pajak Penghasilan. Dimana peraturan ini dibuat untuk mencegah terjadinya tax avoidance dengan cara pembebanan bunga yang terlalu tinggi sebagai biaya operasional perusahaan.

\section{REFERENSI}

Adelopo, I., Yinusa, G., \& Rufai, I. (2019). The Impacts of Multiple Large Ownership Armstrong, C. S., Blouin, J. L., Jagolinzer, A. D., \& Larcker, D. F. (2015). Corporate governance, incentives, and tax avoidance. Journal of Accounting and Economics, 60(1), 1-17. https://doi.org/10.1016/j.jacceco.2015.02.003

Ayu, G., Lestari, W., \& Putri, I. G. A. M. A. D. (2017). Pengaruh Corporate Governance, Koneksi Politik, Dan Leverage Terhadap Penghindaran Pajak. E-Jurnal Akuntansi, 18(3), 2028-2054.

Budiman, Judi., \& Setiyono. (2012). Pengaruh Karakteristik Eksekutif Terhadap Penghindaran Pajak (Tax Avoidance). Simposium Nasional Akuntanasi XV (Banjarmasin).

Chandra, A. F. (2017). Company Size, Profotability, Tangibilitas, Free Cash Flow, and Growth Opportunity that Affect the Capital Structure in Manufacturing Company. Jurnal Manajemen Bisnis Dan Kewirausahaan, 2, 17-27.

Christopher S, Amstrong., Jennifer L. Blouin, Alan D. Jagolinzer, and David F.Larcker. 2015. "Corporate Governance, Incentives, and Tax Avoidance." Journal o Accounting and Economics 60(1):1-17.

Darmawan, I., \& Sukartha, I. (2014). Pengaruh Penerapan Corporate Governance, Leverage, Roa, Dan Ukuran Perusahaan Pada Penghindaran Pajak. E-Jurnal Akuntansi, 9(1), 143-161

Desai, M.A. dan Dharmapala, D. (2007). Corporate tax avoidance and high-powered incentives. Journal of Financial Economics, 79, 145-179.

Dyreng, S.D., Hanlon, M., \& Maydew, E.L. (2008). Long-run corporate tax avoidance.

The Accounting Review, 83, 61-82.

Endriati, Enny., Hidayati, Nur., \& Junaidi. (2013). Pengaruh Perencanaan Pajak Terhadap Manajemen Laba Pada Perusahaan Non Manufaktur Yang Terdaftar Di Bursa Efek Indonesia. Jurnal Universitas Islam Malang.

Fabozzi, F.J. (2007). Bond markets, analysis, and strategies. New Jersey: Prentice Hall.

Ferdiawan, Yopi \& Firmansyah, Amrie. (2017). Pengaruh Political Connection, Foreign Activity, Dan, Real Earnings Management Terhadap Tax Avoidance. Jurnal Riset Akuntansi \& Keuangan ISSN:2541-061X (Online). ISSN:2338-150

Fitriyah. Fury K dan Hidayat, dina. (2011). Pengaruh Kepemilikan Institusional, Set Kesempatan Investasi Dan Arus Kas Bebas Terhadap Beban Hutang. Media Riset Akuntansi, Vol. 1, No.

Ghozali, Imam. (2013). Analisis Multivariat dan Ekonometrika, Teori, Konsep dan Aplikasi dengan Program Eviews 8. Semarang: Badan Penerbit Universitas Diponegoro. 
Graham, J.R., dan Tucker, A. (2006). Tax shelters and corporate debt policy. Journal of Financial Economics, 81, 563-594.

Hanlon, Michelle, dan Shane Heitzman. (2010). A Review of Tax Research. Journal of Accounting and Economics. 5. $127-178$.

Irianto, D. B. S., Sudibyo, Y. A., \& Wafirli, A. (2017). The Influence of Profitability, Leverage, Firm Size and Capital Intensity Towards Tax Avoidance. International Journal of Accounting and Taxation, 5(2), 33-41. https://doi.org/10.15640/ijat.v5n2a3

Iqbal, Muhammad. (2015). Pajak Sebagai Ujung Tombak Pembangunan. Diakses melalui $\quad$ http://www.pajak.go.id/content/article/pajak-sebagai-ujung-tombakpembangunan

Jensen, M., C., \& W. Meckling. (1976.). Theory of the firm: Managerial behavior, agency cost and ownership structure. Journal of Finance Economic 3:305- 360, di-download dari http://www.nhh.no/for/courses/spring/eco420/jensenmeckling-76

Juniarti, \& Sentosa, et al, (2009). Pengaruh Good Corporate Governance, Voluntary Disclosure Terhadap Biaya Hutang (Cost Of Debt). Jurnal Akuntansi dan Keuangan. Vol 11, No. 2, pp. 88-100.

Kholbadalov, Utkir. (2012). The relationship of corporate tax avoidance, cost of debt and institutional ownership: evidence from Malaysia. Atlantic Review of Economics, 2st Volume - 2012.

Kurniasih, Tommy., \& Sari, Maria M.Ratna. (2013). Pengaruh Return on Assets, Leverage, Corporate Governance, Ukuran Perusahaan Dan Kompensasi Rugi Fiskal Pada Tax Avoidance. Buletin Studi Ekonomi, (18). hal. 58-66.

Lee, B. B., Dobiyanski, A., \& Minton, S. (2015). Theories and Empirical Proxies for Corporate Tax Avoidance. Journal of Applied Business and Economics, 17(3), 2134.

Lim, YD. (2011). Tax avoidance, cost of debt and shareholder activism: Evidence from Korea. Journal of Banking \& Finance, 35, 456-470.

Mahrani, S. (2019). Corporate Governance, Profitability, And Liquidity Against Tax Avoidance in Mining Companies Registered On The Indonesia Stock Exchange In 2012-2016. Research Journal of Finance and Accounting, 10(11), 68-78. https://doi.org/10.7176/RJFA

Marcelliana, Elsa., \& Purwaningsih, Anna. (2013). Pengaruh Tax Avoidance Terhadap Cost Of Debt Pada Perusahaan Manufaktur Yang Terdaftar Di Bursa Efek Indonesia Periode 2010-2012. Jurnal Universitas Atma Jaya Yogyakart

Masri, Indah., dan Martani, Dwi. (2012). Pengaruh Tax Avoidance Terhadap Cost of Debt. Fakultas Ekonomi Universitas Indonesia.

Ngadiman., dan Puspitasari, Christiany. (2014). Pengaruh Leverage, Kepemilikan Institusional, Dan Ukuran Perusahaan Terhadap Penghindaran Pajak (Tax Avoidance) Pada Perusahaan Sektor Manufaktur Yang Terdaftar Di Bursa Efek Indonesia 2010-2012. Jurnal Akuntansi, Volume XVIII, No. 03, PP. 408-421.

Purwanti, Nining. (2014). Pengaruh Penghindaran Pajak Terhadap Biaya Hutang Pasca Perubahan Tarif Pajak Badan Pada Perusahaan Manufaktur Yang Terdaftar Di Bursa Efek Indonesia. Jurnal Akuntansi Indonesia, Vol. 3 No. 2 Juli 2014, Hal. 113 $-128$ 
Rodhian, H., \& Zulaikha. (2013). Pengaruh Karakteristik Corporate Governance Terhadap Effective Tax Rate (Studi Empiris Pada BUMN Yang Terdaftar di BEI 2009-2011). Diponegoro Journal Of Accounting, 2(2), 1-10.

Sanusi, Anwar (2011). Metode Penelitian Bisnis. Jakarta: Salemba Empat.

Saputra, Moses Dicky Refa, and Nur Fadjrih Asyik. 2017. "Pengaruh Profitabilitas, Leverage, Dan Corporate Governance Terhadap Tax Avoidance." Jurnal Akuntansi Universitas Negri Padang 6(8):1-19.

Septian, Muhammad dan Panggabean Rosinta Ria . (2017) Faktor- faktor yang mempengaruhi Biaya Utang pada Perusahaan Dalam Kompas 100. Jurnal Ekonomi/Volume XXII, No.01, Maret 2017: 37-51

Soemitro, Rochmat \& Dewi Kania Sugiharti (2010). Asas dan Dasar Perpajakan 1 (Edisi Revisi). Bandung : Refika Aditama.

Sugiono (2018). Manajemen Keuangan Untuk Praktisi Keuangan. Grasindo. Jakarta.

Suandy, Erly. (2011). Perencanaan Pajak, Edisi 5. Jakarta: Salemba Empat

Swingly, Calvin, and I. Made Sukartha. 2015. "Pengaruh Karakter Eksekutif, Komite Audit, Ukuran Perusahaan, Leverage, Dan Sales Growth Pada Tax Avoidance.” EJurnal Akuntansi Universitas Udayana 1:47-62

Wahyuni, L., Fahada, R., \& Atmaja, B. (2019). The Effect of Business Strategy, Leverage, Profitability and Sales Growth on Tax Avoidance. Indonesian Management and Accounting Research, 16(2), 66. https://doi.org/10.25105/imar.v16i2.4686

Warsidi, Pramuka \& Bambang Agus. (2009). Evaluasi Kegunaan Rasio Keuangan dalam Memprediksi Perubahan Laba di Masa yang Akan Datang. Jurnal Akuntansi Manajemen dan Ekonomi, Vol 2:1

Warsono. (2017) . Manajemen Keuangan Perusahaan. Jilid 1. Bayu Media Publishing. Mala 